\title{
YB-I promotes microtubule assembly in vitro through interaction with tubulin and microtubules
}

Konstantin G Chernov $^{\dagger 1}$, Alain Mechulam ${ }^{\dagger 2}$, Nadezhda V Popova ${ }^{1}$, David Pastre ${ }^{2}$, Elena S Nadezhdina1, Olga V Skabkina1, Nina A Shanina ${ }^{3}$, Victor D Vasiliev ${ }^{1}$, Anne Tarrade ${ }^{2}$, Judith Melki ${ }^{4}$, Vandana Joshi², Sonia Baconnais ${ }^{5}$, Flavio Toma ${ }^{2}$, Lev P Ovchinnikov ${ }^{1}$ and Patrick A Curmi*2

\begin{abstract}
Address: ${ }^{1}$ Institute of Protein Research, Russian Academy of Sciences, Pushchino, Moscow Region, 142290 Russia, ${ }^{2}$ Laboratoire Structure-Activité des Biomolécules Normales et Pathologiques, INSERM/UEVE U829 Evry, 91025 France, ${ }^{3}$ Department of Molecular Biology, Biological Faculty of Lomonosov Moscow State University, Moscow, 119991 Russia, ${ }^{4}$ Dept. of Human Genetics, Hadassah University Hospital, Kiryat Hadassah, PO Box 12000, 91120 Jerusalem, Israel and ${ }^{5}$ Laboratoire de Microscopie Moléculaire et Cellulaire, UMR 8126 CNRS-IGR-UPS, Institut GustaveRoussy, 39 rue Camille Desmoulins, 94805 Villejuif, France

Email: Konstantin G Chernov - k-ch@rambler.ru; Alain Mechulam - amechula@univ-evry.fr; Nadezhda V Popova - kostiachernov@gmail.com; David Pastre - david.pastre@univ-evry.fr; Elena S Nadezhdina - elena.nadezhdina@gmail.com; Olga V Skabkina - skabkina@vega.protres.ru; Nina A Shanina - llebouil@univ-evry.fr; Victor D Vasiliev - vasiliev@vega.protres.ru; Anne Tarrade - anne.tarrade@univ-evry.fr; Judith Melki - judithme@ hadassah.org.il; Vandana Joshi - vandana.joshi@univ-evry.fr; Sonia Baconnais - sonia.baconnais@igr.fr; Flavio Toma - flavio.toma@univ-evry.fr; Lev P Ovchinnikov - ovchinn@vega.protres.ru; Patrick A Curmi* - pcurmi@univ-evry.fr

* Corresponding author †Equal contributors
\end{abstract}

Published: I5 September 2008

BMC Biochemistry 2008, 9:23 doi:I0.1 I86/147|-209/-9-23
Received: 25 April 2008

Accepted: 15 September 2008

This article is available from: http://www.biomedcentral.com/|47/-209//9/23

(c) 2008 Chernov et al; licensee BioMed Central Ltd.

This is an Open Access article distributed under the terms of the Creative Commons Attribution License (http://creativecommons.org/licenses/by/2.0), which permits unrestricted use, distribution, and reproduction in any medium, provided the original work is properly cited.

\begin{abstract}
Background: YB-I is a major regulator of gene expression in eukaryotic cells. In addition to its role in transcription, YB-I plays a key role in translation and stabilization of mRNAs.

Results: We show here that YB-I interacts with tubulin and microtubules and stimulates microtubule assembly in vitro. High resolution imaging via electron and atomic force microscopy revealed that microtubules assembled in the presence of $Y B-I$ exhibited a normal single wall ultrastructure and indicated that YB-I most probably coats the outer microtubule wall. Furthermore, we found that YB-I also promotes the assembly of MAPs-tubulin and subtilisintreated tubulin. Finally, we demonstrated that tubulin interferes with RNA:YB-I complexes.
\end{abstract}

Conclusion: These results suggest that YB-I may regulate microtubule assembly in vivo and that its interaction with tubulin may contribute to the control of mRNA translation.

\section{Background}

YB-1 is a multifunctional protein known to interact with nucleic acids, and as such, YB-1 is involved in a wide variety of cellular processes in eukaryotic cells (reviewed in [1]). In the cytoplasm, YB-1 participates in the formation of mRNPs and in the regulation of mRNA translation and degradation [2-6]. In the nucleus, YB-1 functions as a Y- box binding transcription factor, where it activates transcription of various cellular genes, including those implicated in cell growth, differentiation and apoptosis (reviewed in [7]). Translocation of YB-1 from cytoplasm to the cell nucleus can occur at certain steps of the cell cycle [8] and in response to stress-induced DNA damages $[9,10]$. The association of YB-1 with nucleic acids causes 
global changes in their structures by melting short or imperfect duplexes and acceleration of annealing and strand exchange reactions between complementary strands of RNA and DNA $[11,12]$. YB-1 may thus participate in DNA recombination and replication $[13,14]$, and in the case of damaged DNA, YB-1 may assist in its reparation.

Molecular and structural investigations showed that YB-1 interacts with RNA and DNA through two non-homologous domains: the cold-shock domain (CSD), which consists of five anti-parallel beta-strands $[15,16]$, and the Cterminal domain, which contains a series of alternating clusters of positively and negatively charged amino acid residues.

In addition to its interaction with nucleic acids, YB-1 interplays with different protein partners within the cell. It has been noticed that the interaction of YB- 1 with p53 increases the affinity of $\mathrm{p} 53$ for DNA promoters that could stimulate transcription of p53-controled genes $[17,18]$. Similarly, YB-1 interacts with the T-antigen of polyomavirus JC and triggers transcription of viral genes [19]. YB-1 can also catalyze splicing of pre-mRNA via interaction with RNA polymerase II, EWS (Ewing's sarcoma protein) and TLS (translocation liposarcoma protein) proteins [20].

The objective of the present work was to identify new YB1 protein partners to better understand the functions of this protein. We discovered, using a series of biochemical in vitro experiments, that YB-1 strongly interacts with tubulin, both soluble and polymerized into microtubules. We demonstrated that YB-1 stimulates microtubule assembly, and in addition, that tubulin competes with mRNA for interaction with YB-1. In light of these results, we propose that YB-1 may contribute to coordination of regulation of mRNA translation and dynamics of microtubule cytoskeleton. Tubulin, via its interaction with YB-1, may indirectly influence the translational regulation of mRNP complexes.

\section{Results \\ Tubulin is a new YB-I interacting protein}

A search for new YB-1 partners from different rabbit tissue extracts was performed by affinity chromatography using YB-1-Sepharose as bait. Though eluates varied in protein composition, two prominent bands migrating as $45 \mathrm{kDa}$ and $50 \mathrm{kDa}$ were detected in the eluates of most of the tissues (Fig 1A, right panel, marked with an asterisk and a dot, respectively). The $45 \mathrm{kDa}$ protein was identified by MALDI-TOF mass spectrometry as actin, a well-characterized YB-1 partner [21] and the $50 \mathrm{kDa}$ band was identified by similar means as tubulin (see Additional file 1). The presence of tubulin in extract and eluate fractions was also confirmed by Western blotting using anti-alpha and antibeta tubulin antibodies. As shown on Fig. $1 \mathrm{~B}, \alpha$ and $\beta$ tubulin subunits were detected in all tissue extracts and high salt eluates. It is interesting to note that, in the case of brain and testis, some tubulin remained in the flowthrough fraction. This could be either due to the saturation of the affinity column or linked to the sequestration of tubulin with partner proteins. In the control experiments performed with BSA-Sepharose, all tissue proteins were collected in the flow-through fractions and were undetectable in high salt eluates (data not shown). These results strongly suggested that tubulin binds specifically to YB-1.

We further investigated YB-1:tubulin interaction and evaluated the stability of the YB-1-tubulin complex by YB-1 affinity chromatography using pure tubulin as a prey. Tubulin was totally adsorbed on the YB-1-Sepharose column in the presence of $150 \mathrm{mM} \mathrm{NaCl}$, while poorly retained in similar conditions by a casein-Sepharose control column (Fig. 2). Tubulin started to elute from the YB1 column at $300 \mathrm{mM} \mathrm{NaCl}$ forming a peak around 600 $\mathrm{mM} \mathrm{NaCl}$ (Fig. 2). These results indicate that the YB1 :tubulin interaction is not inhibited at physiological and moderate ionic strength (up to $300 \mathrm{mM} \mathrm{NaCl}$ ). We finally probed the presence of YB- 1 and of $\alpha$ and $\beta$ tubulin subunits in YB-1-tubulin complexes by cross-linking using the zero length cross-linker EDC/Sulfo NHS. As displayed on Fig. 3, cross-linker stabilized dimeric forms of YB-1 and $\alpha$ $\beta$-tubulin heterodimers, as well as higher molecular weight aggregates (compare lanes 3 and 4 with 1 and 2). It is worthy to note that under these conditions, both YB1 and tubulin cross-linked samples still contained noncross-linked products (lanes 3 and 4 ). When the crosslinking reaction was performed in the presence of both proteins at a YB-1-tubulin molar ratio of 0.5, most YB-1 was found in high-molecular weight complexes containing also both tubulin subunits (compare lanes 1 and 5). An increase of the YB-1:tubulin molar ratio over 0.5 increased the yield of these high molecular weight complexes (lanes 6 to 8 ) with a slight increase of the free YB-1 band. Our results demonstrate that YB-1 interacts directly with tubulin and suggest that YB-1 contacts the both tubulin subunits in solution.

The binding of YB-1 to tubulin was then investigated by AFM. YB-1 appeared as discrete particles on the mica surface with an average height of $0.7 \mathrm{~nm}$ (Fig. 4, upper panel). This value appeared lower than that reported by Skabkin et al [22] (about $4 \mathrm{~nm}$ for monomeric YB-1 in solution of high ionic strength) and probably resulted from YB-1 flattening on the mica surface. Tubulin appeared as particles with an average height of $3.7 \mathrm{~nm}$ (Fig. 4, middle panel) in agreement with previous reports [23]. In the YB-1-tubulin sample, in contrast to isolated 
A rabbit tissue extracts

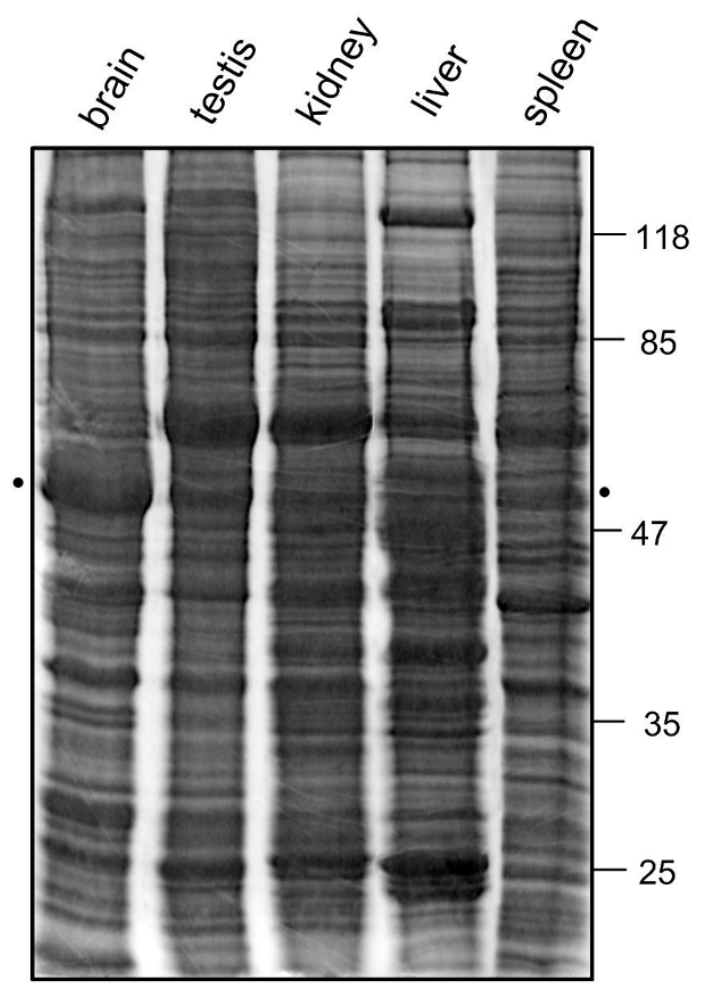

eluates from YB-1 Sepharose

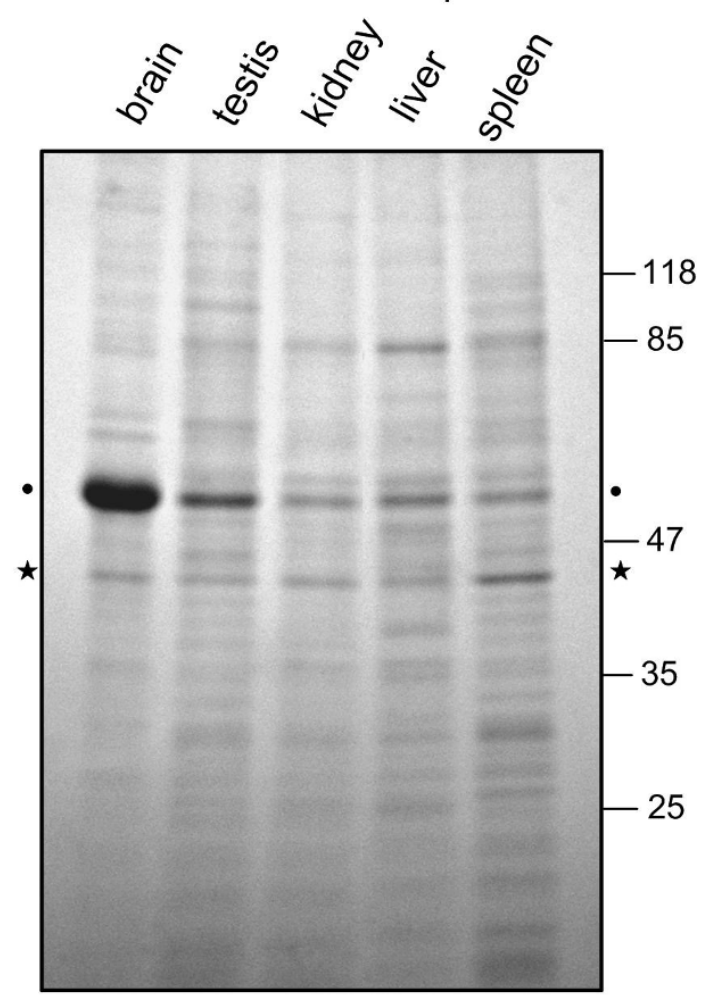

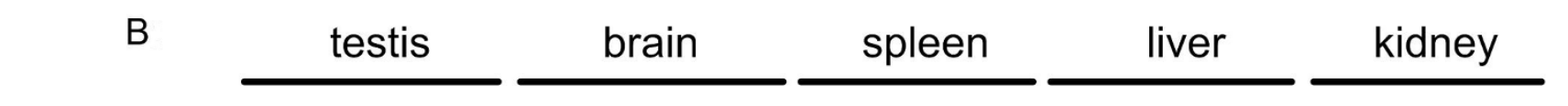

anti- $\alpha$ tubulin

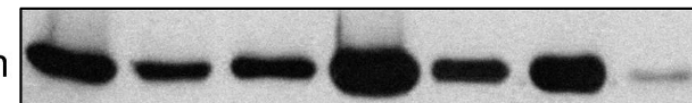

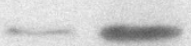

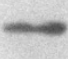

anti- $\beta$ tubulin
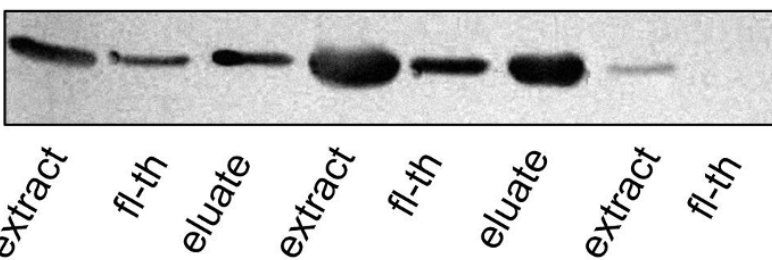

$\vec{\theta}^{\frac{x}{\sigma}} e^{\frac{x}{\sigma}}$
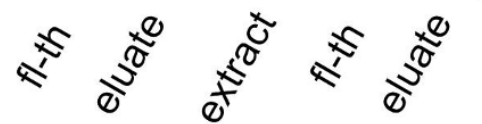

Figure I

YB-I affinity chromatography of rabbit tissue extracts. A, Rabbit tissue extracts ( $50 \mu g$ of total protein) were loaded onto YB-I-Sepharose. After washing with buffer containing $100 \mathrm{mM} \mathrm{KCl}$, bound proteins were eluted with buffer containing I $\mathrm{M} \mathrm{KCl}$. Extracts and eluates were analyzed by $12 \%$ SDS-PAGE followed by Coomassie blue staining. Two prominent bands migrating as $45 \mathrm{kDa}$ and $50 \mathrm{kDa}$ were detected in the eluates of most of the tissues (marked with an asterisk and a dot) and were identified by mass spectrometry as actin and tubulin respectively. B, Western blot of rabbit tissue extracts and YB-ISepharose fractions. Fractions were collected as described in A and probed with anti-alpha and anti-beta tubulin antibodies (flth, flow through).

proteins, particles were less homogenous with a size distribution ranging from about 3 to $8 \mathrm{~nm}$ (Fig. 4, bottom panel). A novel class of particles was clearly distinguishable, centered around $7 \mathrm{~nm}$. It was attributed to the YB-1- tubulin complexes probably made of several molecules of both tubulin and YB-1. 


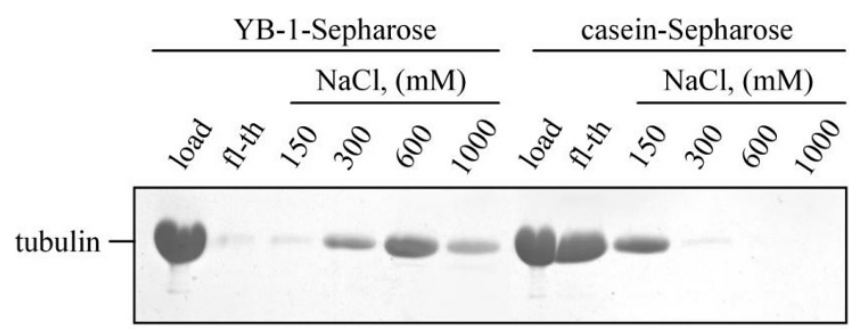

Figure 2

YB-I interacts directly with pure tubulin. Affinity chromatography analysis of YB-I-tubulin interaction. Tubulin (20 $\mu \mathrm{g}$ ) was applied onto $50 \mu \mathrm{l}$ YB-I- or casein-Sepharose (used as a control) in buffer containing $150 \mathrm{mM} \mathrm{NaCl}$ at $4^{\circ} \mathrm{C}$ and incubated for $10 \mathrm{~min}$. After washing, bound proteins were eluted stepwise using buffer containing $150 \mathrm{mM}, 300 \mathrm{mM}$, $600 \mathrm{mM}$ and I $\mathrm{M} \mathrm{NaCl}$ as described under Materials and Methods. Fractions were analyzed by 15\% SDS PAGE followed by Coomassie blue staining.

\section{YB-I strongly favors tubulin assembly in vitro}

The influence of YB-1 on in vitro microtubule assembly was first assessed by turbidimetry. Compared to tubulin control, YB-1 induced a dramatic shortening of the lagtime in a dose dependant manner. It also dose-dependently increased both the apparent rate of microtubule assembly and the steady state plateau value (Fig. 5A and Additional file 4). We next examined the distribution of YB-1 in the soluble tubulin or microtubule fractions in steady-state samples using microtubule sedimentation assay. In agreement with turbidimetry data, the presence of YB-1 strongly increased the total amount of tubulin in the pellet (Fig. 5B). In the presence of $5 \mu \mathrm{M}$ YB-1 and 20 $\mu \mathrm{M}$ tubulin, most of YB-1 was associated with microtubules at steady state. In these conditions, a visual estimation on Coomassie stained gels of the YB-1:tubulin stoichiometry indicated a ratio of about 1 mole of YB-1 per 3 moles of tubulin heterodimer in the pellet. When 20 $\mu \mathrm{M}$ tubulin was assembled in the presence of $10 \mu \mathrm{M}$ YB-1, we noted a further increase of the amount of tubulin in the pellet. YB-1 was again found mainly in the pellet with however a small amount remaining in the supernatant. In these conditions, the YB-1-tubulin stoichiometry in the pellet rose to about 1 mole of YB-1 per 2 moles of tubulin heterodimer. It is worthy to note that YB-1 alone, when centrifuged in the same conditions remained totally in the supernatant fraction (data not shown).

\section{YB-I favors MAPs-tubulin assembly in vitro}

It is well documented that the presence of MAPs strongly influences the kinetics of microtubule assembly. MAPs favor the nucleation of microtubules, increase the rate of assembly, extent of polymerization and stabilize microtubules against disassembly. To investigate whether YB-1 may also influence tubulin polymerization in conditions close to cellular, we performed a series of experiments with MAPs-tubulin. This preparation contained approximately $15 \%$ of MAPs $(\mathrm{w} / \mathrm{w})$ as estimated by Coomassie staining of proteins separated on SDS-PAGE. The addition of YB-1 to MAPs-tubulin at a total YB-1-tubulin ratio of 0.3 decreased the lag-time similarly to pure tubulin, increased the rate of polymerization and slightly increased the final microtubule mass as estimated from the steady state plateau value (Fig. 6). Higher amounts of YB- 1 further reduced the lag-time of polymerization but did not change significantly the mass of polymerized tubulin. These data indicate that the presence of MAPs does not abrogate the positive effect of YB-1 on the overall kinetics of microtubule assembly.

\section{YB-I accelerates tubulin S assembly in vitro}

The C-termini of alpha and beta tubulin subunits are highly negatively charged at physiological $\mathrm{pH}$ and involved in the regulation of tubulin function [24]. On the other hand, YB-1 is highly positively charged at neutral $\mathrm{pH}$, so it was reasonable to think that YB-1 accelerates microtubule assembly via interaction with tubulin C-termini. It was therefore critical to investigate whether the effects of YB- 1 on microtubule assembly could result only from a charge effect or could also be partly due to more specific molecular recognition mechanisms between YB-1 and tubulin. For this purpose, we treated tubulin with subtilisin in such conditions as to cleave the charged Ctermini of the both tubulin subunits and investigated the effect of YB-1 on the assembly of the cleaved tubulin product (tubulin S, Fig. 7A). We observed that YB-1 was still able to promote the assembly of tubulin S (Fig. 7B). A strong stimulation of assembly was observed when YB-1 was added at a total YB-1-tubulin S molar ratio as low as 0.13 . At this ratio, YB-1 significantly decreased the lagtime and increased the velocity of the polymerization (Fig. 7B, curve b). Higher concentrations of YB-1 further reduced the lag-time and increased the rate of tubulin $S$ assembly but did not produce any significant additional effect on microtubule mass at steady-state (Fig. 7B, curves $\mathrm{c}$ and $\mathrm{d}$ ). Together, these data suggest that the promotion of microtubule assembly by YB-1 involves interaction between specific sites of the partners, although non-specific electrostatic interactions may also play an important role.

\section{YB-I promotes the formation of normal microtubules and probably coats the microtubule wall}

High resolution microscopies like AFM or TEM could provide interesting information about microtubule morphology in the presence of YB-1 and about the localization of YB-1 on/in microtubules. Under control conditions, i.e., without YB-1, in AFM images microtubules appeared as straight rods with an apparent height of $10 \mathrm{~nm}$. This indicates that they were flattened on the surface due to the dry- 

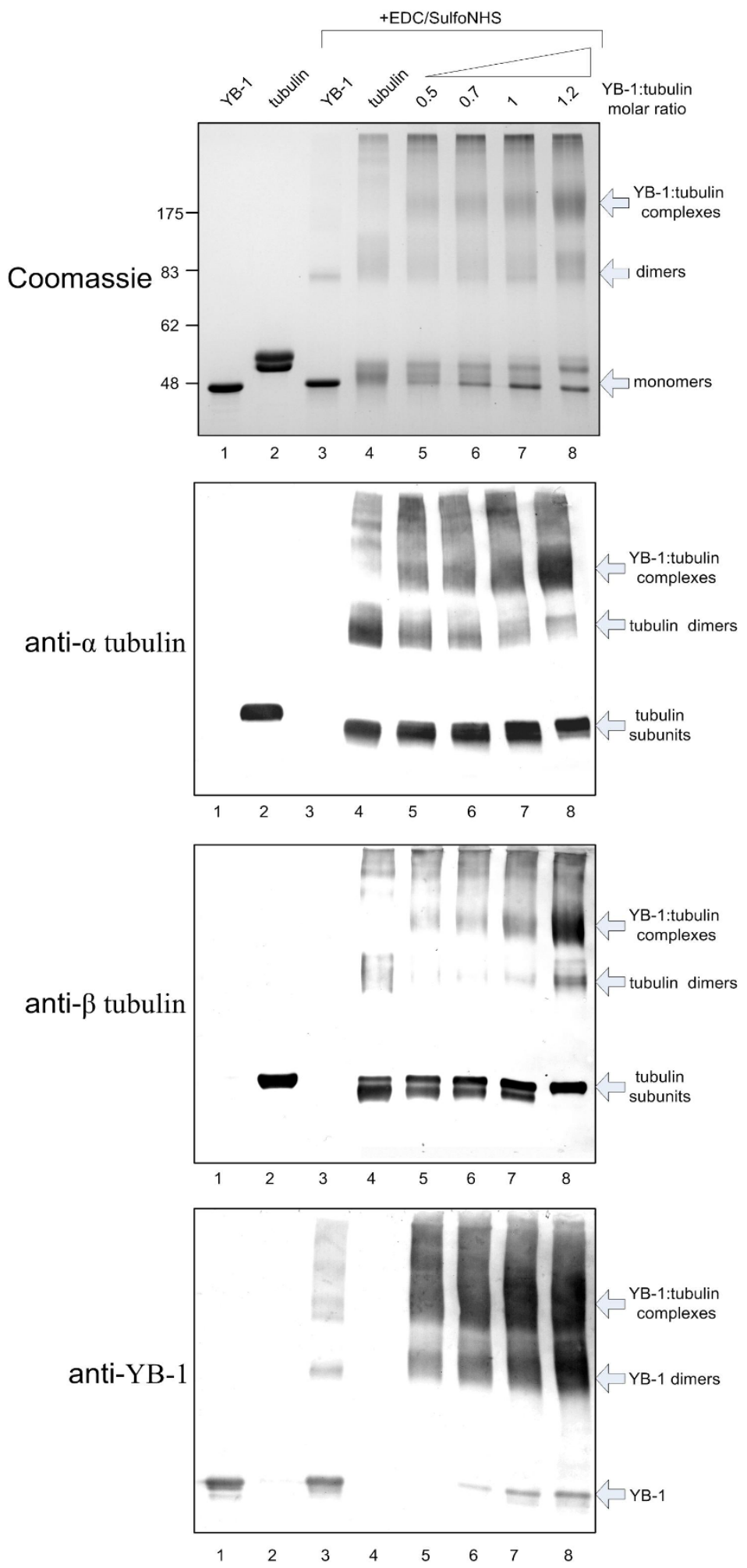

Figure 3

YB-I:tubulin cross-linking. YB-I and tubulin were cross-linked with EDC and sulfo-NHS, resolved by $9 \%$ SDS-PAGE, blotted and probed with anti-alpha, anti-beta tubulin and anti-YB-I antibodies as described under Materials and Methods. Gels were either stained with Coomassie blue (top) or processed for Western blotting with the indicated antibodies. 

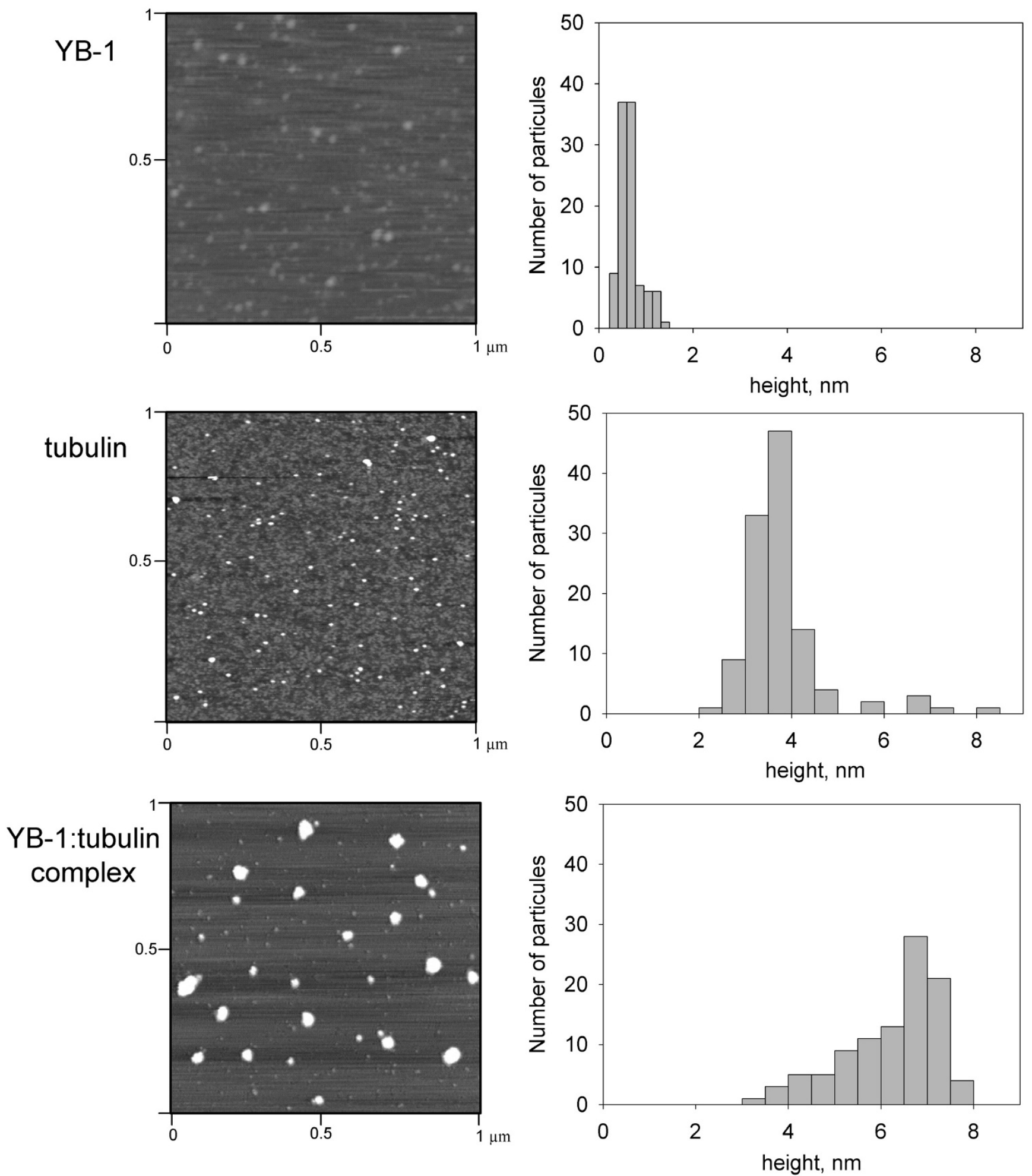

\section{Figure 4}

AFM images of YB-I, tubulin and YB-I-tubulin complexes. Isolated YB-I and tubulin form discrete particles of 0.7 and $3.7 \mathrm{~nm}$ heights, respectively. YB-I-tubulin complex samples formed at a I:I molar ratio show the presence of an additional population of particles with a height of about $7.9 \mathrm{~nm}$. Histograms illustrating the height distribution of particles are displayed on right panels. 

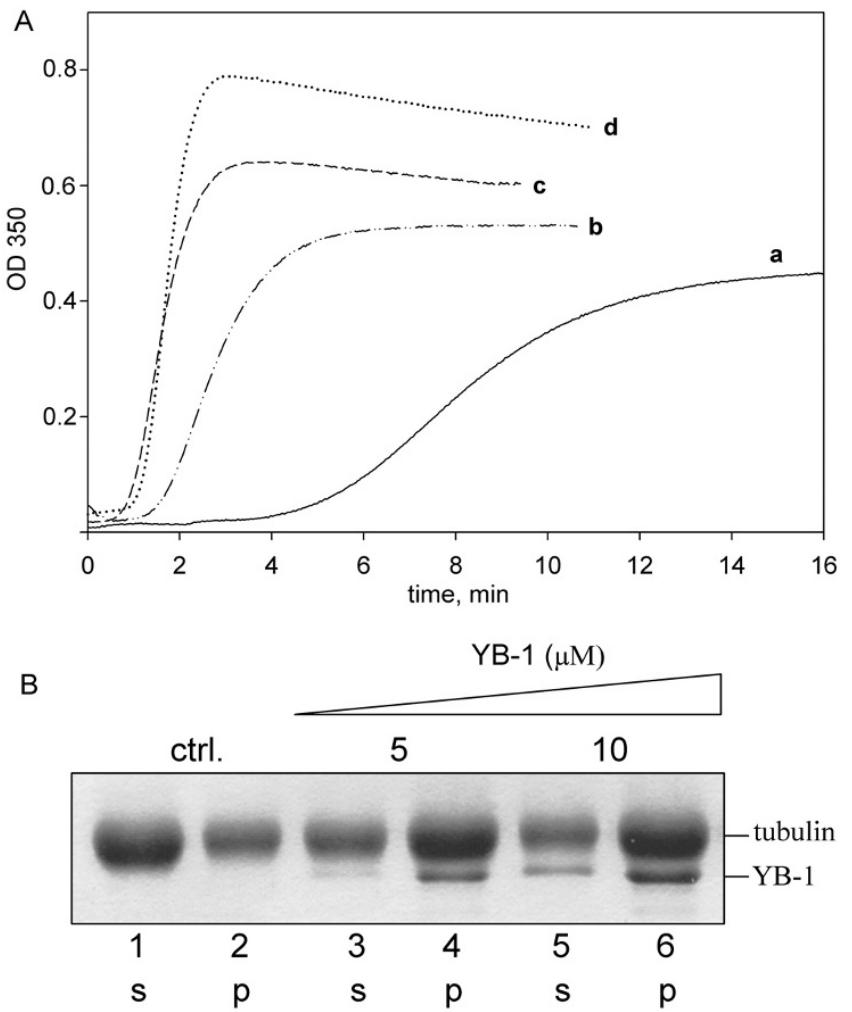

Figure 5

YB-I promotes microtubule assembly and co-sediments with microtubule pellets. A, Turbidimetry plot of $20 \mu \mathrm{M}$ tubulin assembly in the absence (a) or presence of increasing concentrations of YB-I [2.5 $\mu \mathrm{M}$ (b), $5 \mu \mathrm{M}$ (c) and $10 \mu \mathrm{M}$ (d)] in buffer $\mathrm{M}$ with $10 \%$ glycerol. B, $20 \mu \mathrm{M}$ tubulin was polymerized in buffer $M$ with $10 \%$ glycerol in the absence (ctrl) or presence of $5 \mu \mathrm{M}$ or $10 \mu \mathrm{M}$ YB-I. After polymerization until steady-state, the samples were centrifuged, then supernatants and pellets were analyzed by SDS-PAGE. (S, supernatant; $P$, pellet). (Additional file 4).

ing procedure (Fig. 8, upper panel) and the height measurement thus corresponded to two tubulin layers in close contact (see [23] and Fig. 8, upper schema). Microtubules formed in the presence of YB-1 were significantly higher than the control ones with an average height of about $17 \mathrm{~nm}$. The increase in height could correspond to YB-1 coating of the microtubule outer wall (Fig. 8, bottom panel and schema). However, such morphology can also result from microtubules with double walls or with a higher number of protofilaments.

To distinguish between these scenarios, we investigated the effect of YB-1 on the ultrastructure of microtubules by TEM with thin sections of EPON-embedded microtubules. In control conditions, TEM analyses showed regular microtubules with a diameter of about $25 \mathrm{~nm}$. With YB-1, the ultrastructure of microtubules remained normal with

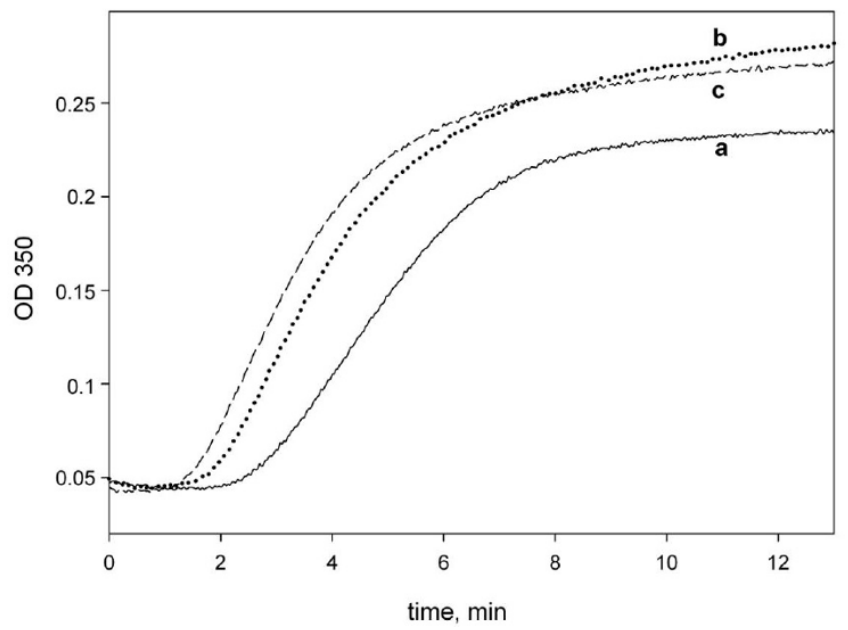

Figure 6

YB-I favors MAPs-tubulin assembly. Turbidimetry plot of MAPs-tubulin ( $\mathrm{mg} / \mathrm{ml}, \sim 9 \mu \mathrm{M})$ assembly in buffer $M$ with $20 \%$ glycerol in the absence (a) or presence of $2.5 \mu \mathrm{M}(\mathrm{b})$, or $5 \mu \mathrm{M}$ YB-I (c).

a single layer of tubulin forming their wall and an outer diameter comparable to control (Fig. 9, compare D' with $\left.\mathrm{C}^{\prime}\right)$. In addition to this, the number of protofilaments was not significantly different from that of control (see Additional file 2). This supported further the suggestion that YB-1 coats the outer surface of the microtubule. It is also worth noting that, under control conditions, microtubules could often be found in close contact with each other (Fig. 9A, C and 9C'), whereas in the presence of YB1 , microtubules appeared regularly distributed and spaced from each other (Fig. 9B, D and 9D'). Due to its coating the microtubule surface, YB-1 could induce a change in rigidity of microtubule or steric hindrance on its outer surface, which may lead to a larger inter-microtubule spacing.

\section{Tubulin interferes with mRNP formation}

YB-1 is a major mRNA binding protein that forms complexes with mRNA and regulates its translational activity. In this context, it is necessary to explore whether tubulin can interfere with formation of RNP and induce some modifications of RNP structure. Since RNP differs from naked RNA in net charge and molecular weight, we decided to investigate the effect of tubulin on YB-1-RNA complexes by electrophoretic mobility gel-shift assay. It is known that RNP saturated with YB-1 contains about one molecule of YB-1 per 25 RNA bases [25]. Compared to RNA alone, these saturated YB-1:RNA complexes demonstrate a significant reduction of mobility in native agarose gel due to either partial RNA discharging or the increased mass of the formed YB-1:RNA complex, or both (Fig. 10, compare lane 1 and 3 ). The presence of tubulin did not 


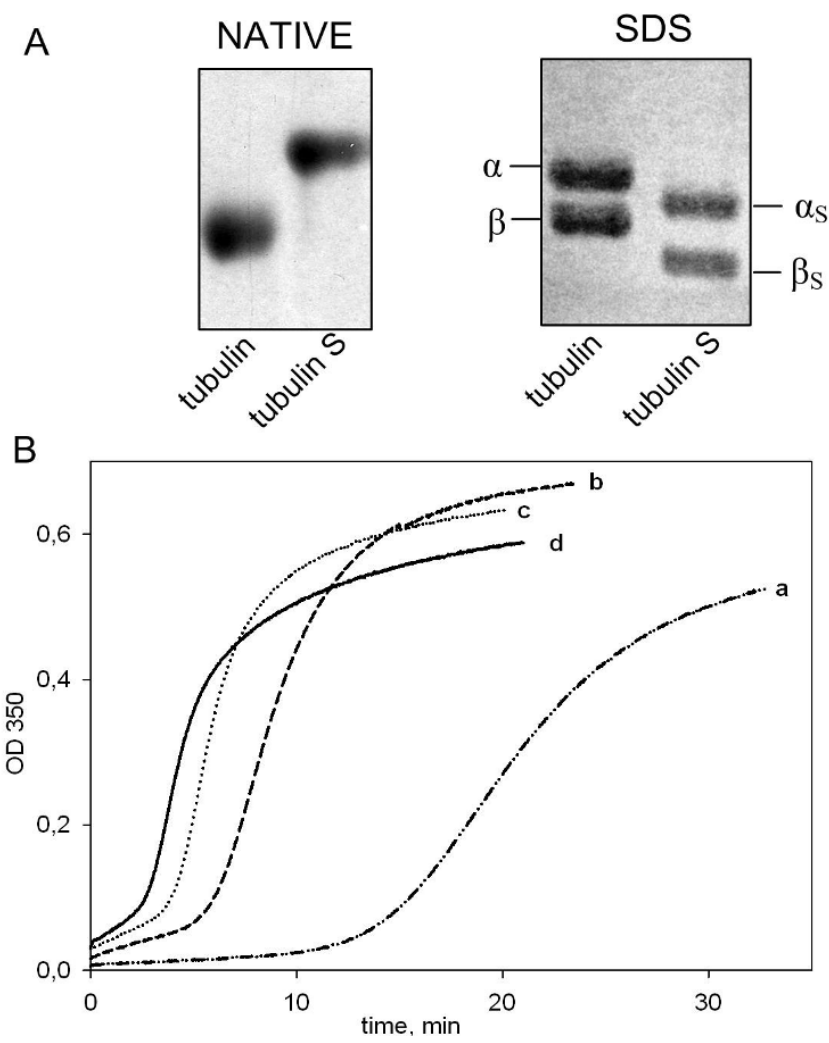

Figure 7

YB-I favors tubulin S assembly. A, Tubulin and tubulin S (5 $\mu \mathrm{M}$ each) were analyzed by native agarose gel (left panel) and $8 \%$ SDS-PAGE (right panel). In our conditions, complete digestion of both $\alpha$ and $\beta$ tubulin were total. B, Turbidimetry plot of tubulin $S(5 \mu \mathrm{M})$ assembly in the absence (a) or presence of $0.625,1.25,2.5 \mu \mathrm{M}$ YB-I (b, c, and d, respectively) in buffer $M$ with $20 \%$ glycerol.

change mobility of RNA that excluded the possibility of direct interaction between these two molecules (compare lanes 1 and 2). The addition of tubulin to YB-1:RNA complexes clearly increased the mobility of RNP (compare lane 3 with 4 and 5). The presence of tubulin may thus induce structural changes of RNP complexes and/or a change in the RNP charge via YB-1 withdrawal mediated by tubulin. Further investigations are required for a better description of the interaction between mRNA:YB-1 complexes and tubulin, which may play an important role in transition of mRNA from silenced to translationally active state.

\section{Discussion}

YB-1 is a member of the Y-box protein family, a family highly conserved among prokaryotes and eukaryotes. In eukaryotes, Y-box proteins are regulators of transcription and translation and play important roles during the devel- opment and in cell proliferation and transformation. Here, we report that YB-1 interacts with tubulin and microtubules in vitro and demonstrate that this protein promotes the assembly of microtubules. This new functional link of cellular proteins seems to be important, since, on the one hand, the regulation of many vital processes, such as cell division, motility and intracellular traffic depends on the fine tuning of the intrinsic dynamics of microtubules by protein partners. The inventory of tubulin partners is not complete and the comprehension of their mechanisms of regulation of microtubule dynamics is still under investigation. On the other hand, with YB-1 being an RNA-binding protein, the study of YB-1:tubulin interaction is highly relevant to further address the competition between tubulin and mRNA for YB-1 binding. The conformational changes of RNP containing YB-1 induced by tubulin may be of particular interest to investigate RNP accessibility for translation and degradation.

\section{YB-I strongly interacts with tubulin}

The strong binding between YB-1 and tubulin was supported by a series of in vitro biochemical data which also demonstrated that the YB-1:tubulin interaction was independent of the presence of other tissue extract components. Since YB-1 is positively charged at neutral pH (pI 9.5) [2] while tubulin is negatively charged ( $\mathrm{pI} \sim 5.6$ ) [26], we assayed if YB-1 interacts with tubulin in a manner similar to that of many other positively charged nucleic acid binding proteins. As tubulin was still retained on a YB-1 column at physiological ionic strength, we concluded that the attraction between tubulin and YB-1 was the result of a strong, short-ranged, electrostatic interactions and (or) other more specific mechanisms like hydrophobic interactions. Additionally, we found that YB-1 did not provoke the formation of huge aggregates containing tubulin, in contrast to other highly cationic proteins like histones [27]. The YB-1-tubulin oligomeric complexes formed in "non-assembly conditions" had their heights about $7 \mathrm{~nm}$ (Fig. 4), which indicated the involvement of a few YB-1 and tubulin molecules in formation of these complexes.

Microtubule polymerization is a two-step process in which tubulin first forms nucleation templates and then adds to and elongates them $[28,29]$. The templates were modelled either in equilibrium with tubulin dimers [3032] or as persistent structures [33]. MAPs facilitate the formation of templates and are thought to clamp them. The YB-1-tubulin complexes we observed here were functionally reminiscent of MAPs-tubulin complexes [29]. The YB1-tubulin complexes could represent nucleation templates, and thus, YB-1 could act as a nucleation factor for microtubule assembly in vitro in a manner similar to that of classical MAPs [34]. 

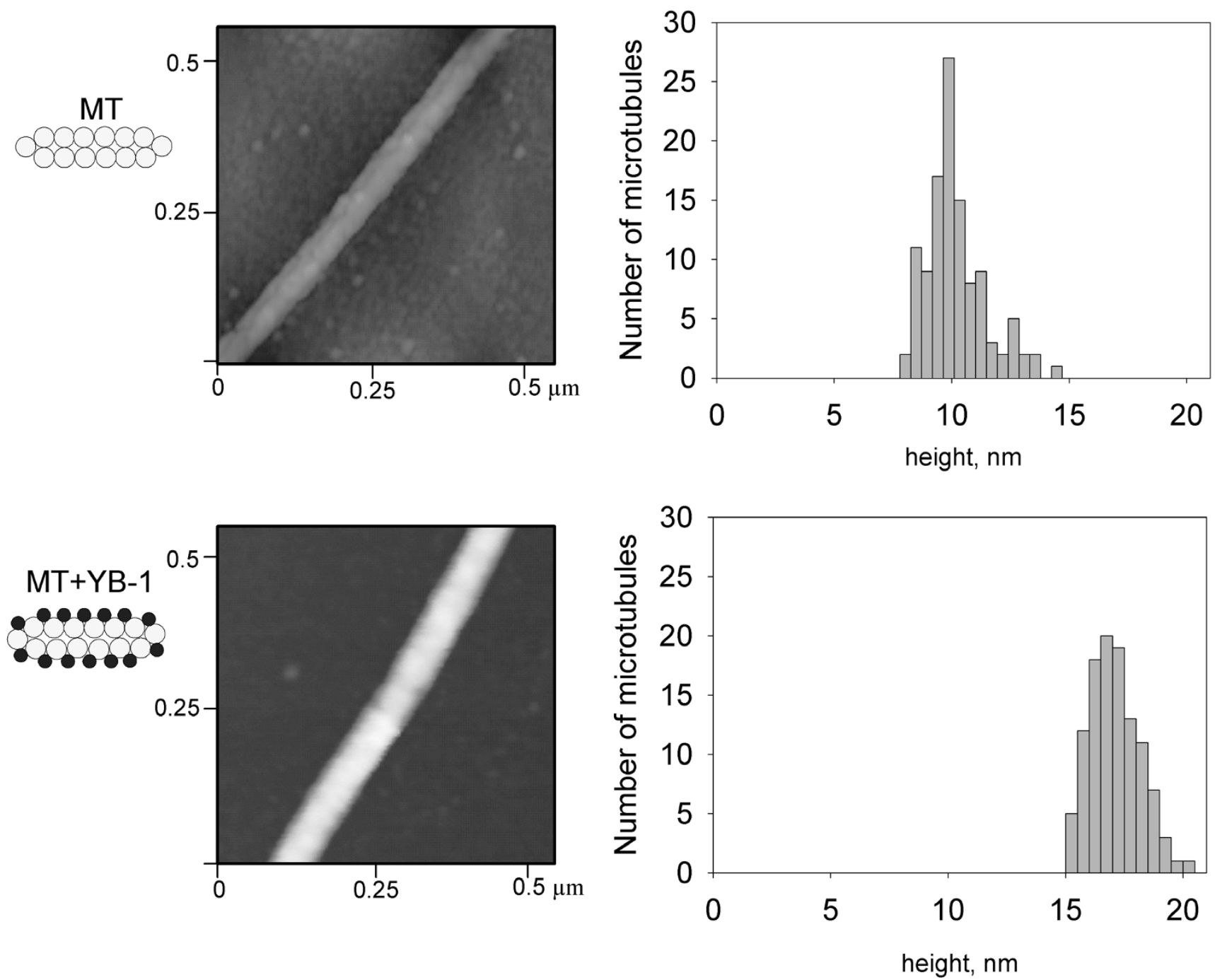

Figure 8

AFM images of microtubules assembled with or without YB-I. Microtubules were assembled with (bottom panel) or without YB-I (top panel), fixed and analyzed by AFM as described under Materials and Methods. Histograms of the microtubule height distribution are shown on the right. Schemas on the left illustrate the proposed structure of microtubules.

\section{YB-I favours microtubule assembly and coats the microtubule wall}

YB-1 strongly favoured polymerization of pure tubulin into microtubules. YB-1 was found to accelerate the apparent rate of microtubule assembly, to increase the microtubule mass at steady state and to be associated with microtubules.

The ability of MAPs or other non-specific basic molecules to promote microtubule assembly depends largely upon the presence of the negative charges of tubulin C-termini $[35,36]$. In contrast to these positively charged molecules, we found that YB-1, which is also a basic protein, still stimulated polymerization of tubulin cleaved by subtili- sin. This observation suggests that the promotion of microtubule assembly by YB-1 results not only from purely electrostatic interactions but also from a more specific molecular recognition mechanism. This suggestion is supported by the fact that most positively charged molecules which interact in a non-specific manner with tubulin promote the assembly of tubulin into aberrant structures instead of microtubules. For example, polycations induce the formation of double-walled microtubules $[37,38]$, and aminoacyl-tRNA synthetases promote microtubule bundling [39]. In the present work, electron microscopy analysis showed that microtubules formed in the presence of YB-1 possess a normal morphology with a single wall of circa $25 \mathrm{~nm}$ diameter and parallel AFM 

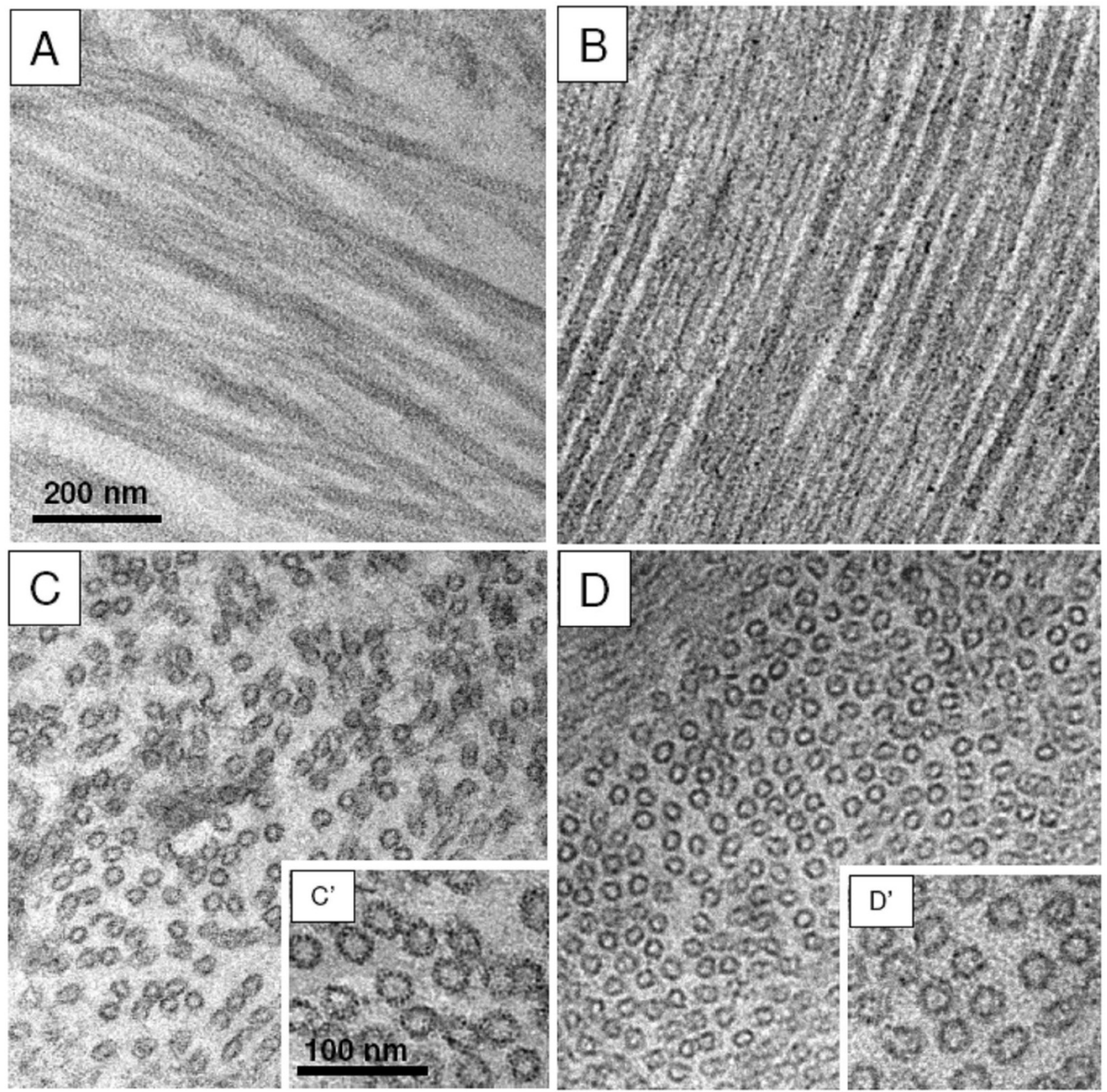

\section{Figure 9}

YB-I induces the formation of single wall microtubules. Tubulin $(30 \mu \mathrm{M})$ was polymerized without $\left(A, C, C^{\prime}\right)$ or with $10 \mu \mathrm{M}$ YB-I (B, D, $\left.D^{\prime}\right)$ at $37^{\circ} \mathrm{C}$. Transmission electron microscopy of longitudinal ultrathin sections revealed that YB-I contributes to the formation of normal microtubules and that, in addition, the microtubules remain regularly spaced from one another (compare B with the control A). Transversal sections of microtubules (C, D) confirmed this observation. B, C, D are at the same magnification as $A$. $D^{\prime}$ is at the same magnification as $C^{\prime}$. 


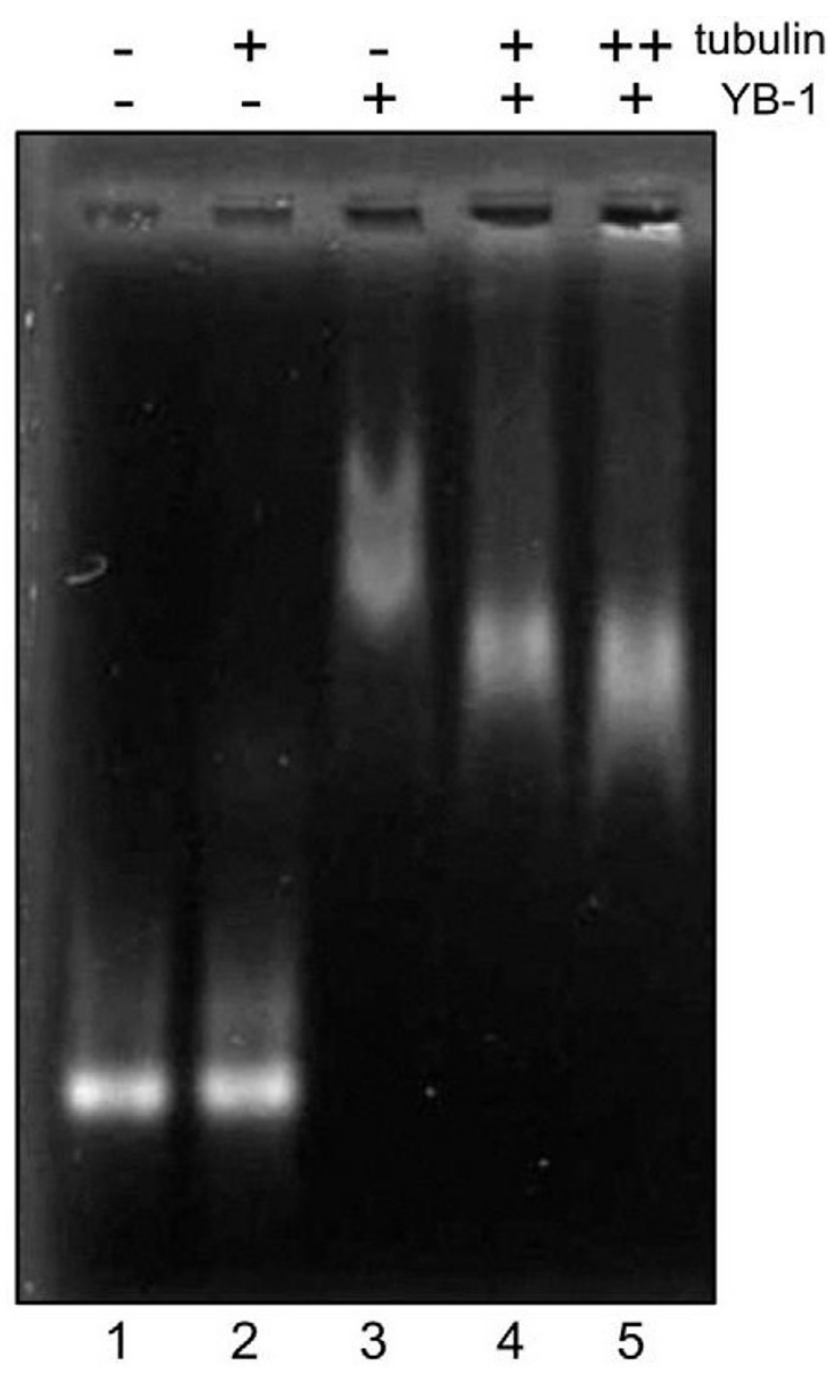

Figure 10

Tubulin modifies the structure of YB-I-RNA complexes. $30 \mathrm{nM}$ Luciferase RNA was incubated in buffer M with $5 \%$ glycerol alone (lanes $I$ and 2 ) or in the presence of 2.I $\mu \mathrm{M}$ YB-I (lanes 3,4 and 5) for $10 \mathrm{~min}$ at $25^{\circ} \mathrm{C}$. After incubation, $2.1 \mu \mathrm{M}$ tubulin (lane 4 ) or $4.2 \mu \mathrm{M}$ tubulin (lanes 2 and 5) were added and mixtures were analyzed by native agarose gel electrophoresis followed by staining with ethidium bromide.

investigations showed that YB-1 can coat the outer surface of the microtubule wall.

In agreement with these microscopic data, YB-1 was found to co-sediment with microtubules (Fig. 5). The stoichiometry corresponds well to some other microtubulebinding proteins with single tubulin dimer-binding site [40,41]. Many canonic MAPs were reported to bind microtubules with a stoichiometry ranging from 1:15 to 1:8 (MAPs:tubulin ratio in the microtubule wall) proba- bly because of multiple tubulin-binding sites and high molecular mass of these proteins [42].

\section{YB-I promotes polymerization of MAPs-tubulin}

In the presence of MAPs-tubulin, YB-1 also accelerated microtubule assembly, although it didn't promote an increase of the total mass of polymerized tubulin. This was most probably due to the fact that our MAPs-tubulin preparation contained around $15 \%$ of MAPs (w/w), which makes microtubules nearly saturated with MAPs. Interestingly, some high molecular weight MAPs were partially displaced by YB- 1 from MAPs-microtubules stabilized with taxol when the total YB-1-tubulin molar ratio was above 0.5 (see Additional file 3). As mentioned above, classical MAPs, such as tau and MAP2, interact mostly with the negatively charged C-termini of tubulin. In addition, tau binds to the amino terminal region of alpha tubulin subunit [43]. Since YB-1 strongly promoted assembly of tubulin lacking C-termini, we predict that YB1 interacts with microtubules not only via non-specific binding to the negatively charged C-terminal tail. Finally, in this context, it is interesting to note that YB-1 doesn't display any homology with classical MAPs and may represent the generic element of a novel class of microtubule interacting proteins.

\section{YB-I may shuttle between mRNA and the microtubule cytoskeleton in vivo}

Microtubules play a critical role in mRNA translation and localization in vivo (reviewed in [44]). Numerous plant proteins known to regulate translation were recently identified by affinity chromatography as tubulin-binding proteins [45]. For example, the plant initiation factor eIF(iso) $4 \mathrm{~F}$ was found associated with the microtubule cytoskeleton in the cell and is able to induces microtubule bundling in vitro [46].

Since YB-1 is a major component of cellular RNPs, interaction of tubulin with YB-1 could potentially regulate the translation state of mRNAs. Indeed, YB-1 protects mRNAs from degradation and packs them in non-translatable RNPs. We have shown here that tubulin changes the electrophoretic mobility of YB-1-RNA complexes. This change most probably occurs due to the partial dissociation of YB-1 from RNA, which could be a signal to trigger mRNA translation and/or degradation. Interestingly, it has recently been shown that the phosphorylation of YB- 1 by Akt kinase may regulate its binding to mRNA [47]. It is thus expected that the phosphorylated form of YB-1, which possesses a lower affinity for the cap-structure of mRNA, could be more easily released from RNA than its non-phosphorylated form. This release could occur due to interaction of mRNA with other RNA-binding proteins or through the interaction of YB-1 with protein partners, such as tubulin. Our results thus provide new prospects 
on the role of protein-protein interaction in the regulation of mRNA translation. Furthermore, these results could also help to unravel situations where tubulin is involved in the overall processes of mRNA translation and degradation.

\section{Conclusion}

Thus, we have first demonstrated that YB-1 stimulates microtubule assembly in vitro. By all in vitro criteria, YB-1 represents a novel microtubule-interacting protein related to the function of MAPs but clearly with different properties. The YB-1 properties described here may contribute to the understanding of its role in the cell division and embryogenesis and shed light on its oncogenic and antioncogenic activities [48-51]. Finally, these results could provide a framework to bridge different aspects of regulation of mRNA translation and the function of the microtubule cytoskeleton.

\section{Methods}

Unless stated otherwise, chemicals were purchased from Sigma-Aldrich (Milwaukee, WI, USA).

\section{YB-I purification}

YB-1 was expressed in the Escherichia coli BL21(DE3) strain transformed with the pET 3-1-YB-1 construct [12]. Bacteria were cultured at $37^{\circ} \mathrm{C}$ to mid-log exponential phase, then protein synthesis was induced by $0.5 \mathrm{mM}$ IPTG. After $3 \mathrm{~h}$ induction, bacteria were pelleted by centrifugation $(4000 \times \mathrm{g}, 10 \mathrm{~min})$ and the pellet was resuspended in 10 volumes of $40 \mathrm{mM}$ Tris- $\mathrm{HCl}, \mathrm{pH} 7.6,2 \mathrm{M}$ $\mathrm{NaCl}, 1 \mathrm{mM}$ PMSF and disrupted by ultrasonication. Cell debris was removed by centrifugation at $140000 \times \mathrm{g}$ for 2 h. Supernatant was diluted with four volumes of $10 \mathrm{mM}$ Tris-HCl, $\mathrm{pH}$ 7.6, and loaded onto a heparin-Sepharose column (GE Healthcare, UK) equilibrated with $20 \mathrm{mM}$ Tris-HCl, pH 7.6, $500 \mathrm{mM} \mathrm{NaCl}$. The column was washed with 5 volumes of $20 \mathrm{mM}$ Tris- $\mathrm{HCl}, \mathrm{pH} 7.6,500 \mathrm{mM}$ $\mathrm{NaCl}$, after that bound YB- 1 was eluted with $20 \mathrm{mM}$ Tris$\mathrm{HCl}, \mathrm{pH}$ 7.6, $2 \mathrm{M} \mathrm{NaCl}$. Eluted protein was concentrated by centrifugation using a Centriprep 10 concentrator (Amicon Corporation, Danvers, MA) and purified by size exclusion chromatography on a Sephacryl S-200 column (GE Healthcare) pre-equilibrated with $20 \mathrm{mM}$ Tris- $\mathrm{HCl}$, $\mathrm{pH}$ 7.6, $2 \mathrm{M} \mathrm{NaCl}$. Fractions containing YB-1 were pooled, dialyzed against $20 \mathrm{mM}$ Tris- $\mathrm{HCl}, \mathrm{pH} 7.6,250 \mathrm{mM} \mathrm{NaCl}$ and concentrated again using the same procedure. Protein concentration was determined by comparison with a standard BSA curve using the Bio-Rad protein assay kit (Bio-Rad Laboratories, Richmond, CA). Anti-YB-1 antibodies were produced in rabbit as described by Davydova et al. [52].

\section{Tubulin and microtubule proteins preparation}

Tubulin was purified from sheep brain using the method of Castoldi and Popov [53] and stored at $-80^{\circ} \mathrm{C}$ in $50 \mathrm{mM}$ MES-KOH, pH 6.8, $0.5 \mathrm{mM}$ dithiothreitol, $0.5 \mathrm{mM}$ EGTA, $0.25 \mathrm{mM} \mathrm{MgCl}_{2}, 3.4 \mathrm{M}$ glycerol, $0.1 \mathrm{mM}$ GTP. Before use, tubulin stock was thawed and an additional cycle of polymerization was performed. Microtubule proteins (tubulin + microtubule-associated proteins, MAPs, herein referred to as MAPs-tubulin) were purified from sheep brain through two cycles of assembly/disassembly as described by Mitchison and Kirschner [54] aliquoted and stored at $-80^{\circ} \mathrm{C}$. Before use, MAPs-tubulin preparation was rapidly thawed and centrifuged at $25000 \times \mathrm{g} 10 \mathrm{~min}$ to remove aggregated material.

\section{Tubulin S preparation}

Tubulin $S$ was prepared as described by Knipling et al. [55]. Briefly, $250 \mu \mathrm{M}$ tubulin in the stock buffer was diluted five times with $1 \mathrm{mM}$ GTP in water. Subtilisin was then added to reach a subtilisin/tubulin ratio of $1 / 200(\mathrm{w} /$ w). The mixture was incubated for $40 \mathrm{~min}$ at $25^{\circ} \mathrm{C}$, and PMSF was added to $0.5 \mathrm{mM}$ to stop cleavage. We then added MES-KOH, $\mathrm{pH} 6.8, \mathrm{MgCl}_{2}$ and EGTA to reach a final concentration of $50 \mathrm{mM}, 1 \mathrm{mM}$ and $1 \mathrm{mM}$ of these compounds, respectively. The mixture was incubated on ice for $30 \mathrm{~min}$ and centrifuged at $100000 \times \mathrm{g}$ for $10 \mathrm{~min}$. Supernatant was collected and used immediately for polymerization assays.

\section{Rabbit tissue extracts preparation}

Tissue extracts from adult rabbit were prepared as described by Miwa et al [56]. Briefly, tissues were homogenized in 3 volumes of $50 \mathrm{mM}$ Tris- $\mathrm{HCl}, \mathrm{pH} 7.6,50 \mathrm{mM}$

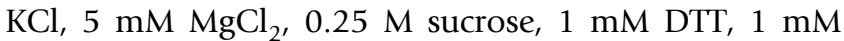
PMSF in motor-driven homogenizer, and homogenates were centrifuged at $10000 \times \mathrm{g}$ for $20 \mathrm{~min}$ to remove cell debris. Supernatants were collected and protein concentration was determined as described above.

\section{Affinity chromatography}

YB-1, BSA and casein were coupled to Sepharose 4B using $5 \mathrm{mg}$ of protein per $1 \mathrm{ml}$ of CNBr-activated Sepharose 4B (GE Healthcare) according to the manufacturer's instructions.

Rabbit tissue extracts ( $50 \mu \mathrm{g}$ of total protein) were incubated with $10 \mu \mathrm{l}$ of YB-1- or BSA-coupled Sepharose in 50 $\mu \mathrm{l}$ of low salt buffer $(20 \mathrm{mM}$ Tris-HCl, $\mathrm{pH}$ 7.6, $100 \mathrm{mM}$ $\mathrm{KCl}, 1 \mathrm{mM} \mathrm{MgCl} 2,1 \mathrm{mM} \mathrm{DTT}, 1 \mathrm{mM}$ PMSF) for $10 \mathrm{~min}$ at room temperature. Reaction mixtures were centrifuged at $1500 \times \mathrm{g}$ for $1 \mathrm{~min}$, supernatants were discarded, and the resin pellets were resuspended in $250 \mu \mathrm{l}$ of incubation buffer and pelleted again. This washing step was repeated twice. Bound proteins were eluted with $250 \mu \mathrm{l}$ of high-salt buffer (20 mM Tris-HCl, pH 7.6, $1 \mathrm{M} \mathrm{KCl}$, pH 7.6, 1 mM 
$\mathrm{MgCl}_{2}, 1 \mathrm{mM}$ DTT, $1 \mathrm{mM}$ PMSF) and precipitated by addition of $75 \%$ acetone $(\mathrm{v} / \mathrm{v})$. Dried pellets were dissolved in SDS sample buffer and analyzed by electrophoresis on $12 \%$ SDS-PAGE. For the identification of tubulin, proteins were separated similarly by SDS-PAGE and then blotted on nitrocellulose as described [57]. Nitrocellulose membranes were blocked with $1 \%$ nonfat milk in TBST buffer (10 mM Tris-HCl, pH 7.6, $140 \mathrm{mM} \mathrm{NaCl}, 0.1 \%$ Triton X-100) and probed for tubulin with mouse anti-alpha (clone B-5-1-2) and anti-beta tubulin antibodies (clone Tub 2.1) diluted at $1 / 5000$ in blocking solution. Primary antibodies were detected using goat anti-mouse horseradish peroxidase conjugated secondary antibodies followed by development using 3,3',5,5'-tetramethylbenzidine (TMB).

\section{Analysis of YB-I:tubulin complex stability}

Tubulin $(20 \mu \mathrm{g})$ was loaded onto $50 \mu \mathrm{l}$ of YB-1- or caseincoupled Sepharose 4B columns equilibrated with $10 \mathrm{mM}$ Tris-HCl, pH 7.6, $150 \mathrm{mM} \mathrm{NaCl}$ and incubated for $10 \mathrm{~min}$ at $4{ }^{\circ} \mathrm{C}$. Flow-through was collected, and the resins were washed with five column volumes of equilibrium buffer. Bound tubulin was eluted stepwise using five column volumes of $10 \mathrm{mM}$ Tris-HCl, $\mathrm{pH}$ 7.6, containing either 300 $\mathrm{mM}, 600 \mathrm{mM}$ or $1 \mathrm{M} \mathrm{NaCl}$. Proteins from all fractions were precipitated by addition of trichloroacetic acid to $10 \%$ and analyzed by SDS-PAGE.

\section{In vitro tubulin polymerization assays}

Tubulin or MAPs-tubulin assembly was followed turbidimetrically at $340 \mathrm{~nm}(1 \mathrm{~cm}$ light path) in an Ultrospec 3000 spectrophotometer (GE Healthcare) equipped with a temperature controller. Experiments were carried out in buffer M (50 mM MES-KOH pH 6.8, 1 mM EGTA, 5 mM $\mathrm{MgCl}_{2}$ and $1 \mathrm{mM}$ GTP) with either 10 or $20 \%$ glycerol (v/ $\mathrm{v})$.

\section{Microtubule sedimentation assays}

$50 \mu \mathrm{l}$ of $25 \mu \mathrm{M}$ tubulin in buffer M containing $10 \%$ glycerol were assembled at $37^{\circ} \mathrm{C}$ with increasing concentrations of YB-1 for $30 \mathrm{~min}$ to reach the steady-state. Microtubules were pelleted at $300000 \times \mathrm{g}$ for $5 \mathrm{~min}$ at $37^{\circ} \mathrm{C}$ and resuspended in $50 \mu \mathrm{l}$ of SDS sample buffer. To determine the amounts of tubulin and YB-1 in the microtubule or supernatant fractions, $3 \mu \mathrm{l}$ of supernatants and resuspended pellets were analyzed by SDS-PAGE.

\section{Cross-linking of YB-I:tubulin complexes}

Cross-linking reactions were performed at tubulin concentration far below the critical concentration. To prepare YB-1:tubulin complexes, $1 \mu \mathrm{M}$ tubulin and $0.3,0.5,0.8$ or $1.2 \mu \mathrm{M}$ YB-1 were incubated in $50 \mathrm{mM}$ MES-KOH, $\mathrm{pH}$ 6.8, $1 \mathrm{mM} \mathrm{MgCl}_{2}, 1 \mathrm{mM}$ EGTA, 0,5 mM GTP, $5 \mathrm{mM}$ EDC, 12 $\mathrm{mM}$ sulfo-NHS for $1 \mathrm{~h}$ at $30^{\circ} \mathrm{C}$. Cross-linking reactions were quenched by the addition of $50 \mathrm{mM}$ glycin. Proteins were precipitated with $75 \%$ acetone, dissolved in SDS sample buffer and resolved on 9\% SDS-PAGE. Protein detection was performed using rabbit anti-YB-1 antibodies [52], anti-alpha tubulin antibodies and anti-beta tubulin antibodies as described above.

\section{Atomic Force Microscopy (AFM)}

To study YB-1:tubulin complexes, we prepared reaction mixtures with either both or separately taken tubulin and YB-1 ( $1 \mu \mathrm{M}$ each) in $50 \mathrm{mM}$ MES-KOH, pH 6.8, $1 \mathrm{mM}$ $\mathrm{MgCl}_{2}, 1 \mathrm{mM}$ EGTA, $0.5 \mathrm{mM}$ GTP. These mixtures were incubated for $10 \mathrm{~min}$ at $37^{\circ} \mathrm{C}$, then fixed with $0.2 \%$ glutaraldehyde.

Microtubules were prepared for AFM imaging as follows: $5 \mu \mathrm{M}$ tubulin was assembled with or without (control) 5 $\mu \mathrm{M}$ YB-1 in $50 \mathrm{mM}$ MES-KOH, pH 6.8, 1 mM EGTA, 5 $\mathrm{mM} \mathrm{MgCl} 2,1 \mathrm{mM} \mathrm{GTP}$, and $20 \mu \mathrm{M}$ taxol for $15 \mathrm{~min}$ at $37^{\circ} \mathrm{C}$, pelleted as described above, gently resuspended in a starting volume of polymerization buffer with $0.2 \%$ glutaraldehyde and fixed for $15 \mathrm{~min}$ at $37^{\circ} \mathrm{C}$.

All AFM samples were deposited on $\mathrm{Ni}^{2+}$ pretreated freshly cleaved mica as described by Pastre et al. [58]. AFM imaging was performed in tapping mode with a multimode AFM instrument (Digital Instruments, Veeco, Santa Barbara, CA) operating with a Nanoscope IIIa controller. We used AC160TS silicon cantilevers (Olympus, Hamburg, Germany) with a resonance frequency of $300 \mathrm{kHz}$. Images were collected at a scan frequency of $1.5 \mathrm{~Hz}$ and a resolution of $512 \times 512$ pixels.

\section{Transmission Electron Microscopy (TEM)}

For ultrathin sectioning, microtubules were prepared with $30 \mu \mathrm{M}$ tubulin with or without $10 \mu \mathrm{M}$ YB-1 in $50 \mathrm{mM}$ MES-KOH, pH 6.8, $1 \mathrm{mM}$ EGTA, $5 \mathrm{mM} \mathrm{MgCl}_{2}$ and $1 \mathrm{mM}$ GTP, $10 \%$ glycerol. Microtubules were pelleted at 40000 $\times \mathrm{g}$ for $30 \mathrm{~min}$ at $37^{\circ} \mathrm{C}$. The pellets were gently resuspended in $50 \mathrm{mM}$ MES-KOH, pH 6.8, 1 mM EGTA, $5 \mathrm{mM}$ $\mathrm{MgCl}_{2}, 1 \mathrm{mM}$ GTP, $1 \%$ glutaraldehyde and incubated for fixation for 1 hour at room temperature. Samples were then post-fixed with $1 \%$ osmium tetraoxide $\left(\mathrm{OsO}_{4}\right)$ for 1 h. After gradual dehydratation in ethanol series, the pellets were embedded in EPON mixture. Ultrathin sections were stained with $2 \%$ uranyl acetate and examined with a Tecnai F20 S-Twin transmission electron microscope (FEI company, Hillsboro, OR, USA) operating at $200 \mathrm{kV}$.

\section{Electrophoretic mobility shift assay}

Luciferase RNA (1500 base length) was synthesized in vitro as described by Svetlov et al [59]. RNA (0.6 pmoles) was incubated in $20 \mu \mathrm{l}$ of buffer $\mathrm{M}$ containing $5 \%$ glycerol alone or in the presence of 42 pmoles YB-1 for $10 \mathrm{~min}$ at room temperature. After incubation, either 42 pmoles or 84 pmoles tubulin were added to preformed RNP. The 
reaction products were separated at $80 \mathrm{~V}$ for 2 hours on $0.6 \%$ agarose gel prepared in buffer M. After migration, the gel was stained with ethidium bromide.

\section{Abbreviations}

MT: microtubules; MAPs: microtubule associated proteins; RNP: ribonucleoprotein; Tubulin S: subtilisintreated tubulin; TEML: transmission electron microscopy; EDC: 1-ethyl-3-(3-dimethylaminopropyl) carbodiimide; Sulfo-NHS: N-hydroxysulfosuccinimide.

\section{Authors' contributions}

KGC: Designed and performed experiments. Participated to the analysis of data, to the writing of the manuscript and revision. AM: Performed experiments, participated to the analysis of data and critical revision. NVP: carried out initial experiments on affinity chromatography of cell extracts and tubulin on YB-1-Sepharose, participated in experiments on YB-1 co-sedimentation with microtubules and in manuscript drafting. DP: Performed AFM investigation, participated to the revision of the manuscript. ESN: was involved in the study design and drafting the manuscript and in revising it critically for important intellectual content. OV: carried out the molecular genetic studies and YB-1 purification and affinity chromatography, coordinated studies on YB-1-tubulin interaction and on analysis of stability of this complex. NAS: isolated tubulin and obtained microtubules, participated in experiments on YB-1-microtubule interaction. VDV: participated in analysis and interpretation of AFM and TEM data and in revising the manuscript. AT: performed TEM. JM: participated to TEM. VJ: production and purification of recombinant protein. SB: participated to TEM. FT: participated to critical review of manuscript. LPO: Conceived of study, participated in design and coordination. PAC: Conceived of study, participated in design and coordination, participate to the writing and revision of the manuscript. All authors read and approved the final manuscript.

\section{Additional material}

\section{Additional file 1}

MALDI-TOF peptide scores for proteins found in eluates after chromatography of rabbit tissue extracts on YB-1-Sepharose.

Click here for file

[http://www.biomedcentral.com/content/supplementary/1471-

2091-9-23-S1.doc]

\section{Additional file 2}

Histogram of protofilament number observed in control microtubules and in the presence of $Y B-1$.

Click here for file

[http://www.biomedcentral.com/content/supplementary/14712091-9-23-S2.jpeg]

\section{Additional file 3}

YB-1 partially displaces MAPs from taxol-stabilized microtubules. MAPstubulin $(0.5 \mathrm{mg} / \mathrm{ml}, \sim 4 \mu \mathrm{M})$ was polymerized in the absence (control) or presence of increasing concentrations of YB-1 (from $1.25 \mu \mathrm{M}$ to $10 \mu \mathrm{M}$, as indicated) in buffer $M$ with $10 \%$ glycerol and $20 \mu \mathrm{M}$ taxol. After polymerization, the samples were pelleted, and equal volumes of supernatants and resuspended pellets were analyzed by SDS-PAGE. (S, supernatant; $P$, pellet).

Click here for file

[http://www.biomedcentral.com/content/supplementary/14712091-9-23-S3.jpeg]

\section{Additional file 4}

Plot of the tangent at the microtubule assembly slope versus YB-1 concentration observed on figure 5. We can notice that rate of microtubule assembly reaches a maximum plateau value from about $8 \mu \mathrm{M} Y B-1$. Click here for file

[http://www.biomedcentral.com/content/supplementary/14712091-9-23-S4.pdf]

\section{Acknowledgements}

Authors thank INSERM, The Conseil Régional d'lle de France; the "Service pour la Science, la Technologie et l'Espace (SSTE)" from French Embassy at Moscow, Russia; Genopole Evry, and the AFM. This study was partly supported by the Programs on "Molecular and Cellular Biology" and on "Basic Sciences to Medicine" from the Presidium of Russian Academy of Sciences.

\section{References}

I. Kohno K, Izumi H, Uchiumi T, Ashizuka M, Kuwano M: The pleiotropic functions of the $Y$-box-binding protein, YB-I. BioEssays 2003, 25:69|-698.

2. Minich WB, Maidebura IP, Ovchinnikov LP: Purification and characterization of the major $50-\mathrm{kDa}$ repressor protein from cytoplasmic mRNP of rabbit reticulocytes. Eur J Biochem 1993 , 2| 2:633-638.

3. Evdokimova $\mathrm{V}$, Ruzanov $\mathrm{P}$, Imataka H, Raught B, Svitkin $\mathrm{Y}$, Ovchinnikov LP, Sonenberg N: The major mRNA-associated protein YB- $I$ is a potent 5 ' cap-dependent $m$ RNA stabilizer. EMBO J 2001, 20:549I-5502.

4. Skabkina OV, Lyabin DN, Skabkin MA, Ovchinnikov LP: YB-I autoregulates translation of its own mRNA at or prior to the step of 40S ribosomal subunit joining. Mol Cell Biol 2005, 25:3317-3323.

5. Evdokimova VM, Kovrigina EA, Nashchekin DV, Davydova EK, Hershey JW, Ovchinnikov LP: The major core protein of messenger ribonucleoprotein particles $(\mathrm{p} 50)$ promotes initiation of protein biosynthesis in vitro. J Biol Chem 1998, 273:3574-358I.

6. Nekrasov MP, Ivshina MP, Chernov KG, Kovrigina EA, Evdokimova VM, Thomas AA, Hershey JW, Ovchinnikov LP: The mRNA-binding protein YB-I (p50) prevents association of the eukaryotic initiation factor elF4G with mRNA and inhibits protein synthesis at the initiation stage. J Biol Chem 2003, 278:13936-13943.

7. Swamynathan SK, Nambiar A, Guntaka RV: Role of single-stranded DNA regions and $Y$-box proteins in transcriptional regulation of viral and cellular genes. FASEB J 1998, I 2:5 I5-522.

8. Jurchott K, Bergmann S, Stein U, Walther W, Janz M, Manni I, Piaggio G, Fietze E, Dietel M, Royer HD: YB-I as a cell cycle-regulated transcription factor facilitating cyclin $A$ and cyclin $B I$ gene expression. J Biol Chem 2003, 278:27988-27996.

9. Koike K, Uchiumi T, Ohga T, Toh S, Wada M, Kohno K, Kuwano M: Nuclear translocation of the $Y$-box binding protein by ultraviolet irradiation. FEBS Lett 1997, 4 I 7:390-394.

10. Sorokin AV, Selyutina AA, Skabkin MA, Guryanov SG, Nazimov IV, Richard C, Th'ng J, Yau J, Sorensen PH, Ovchinnikov LP, Evdokimova $\mathrm{V}$ : Proteasome-mediated cleavage of the $\mathrm{Y}$-box-binding pro- 
tein I is linked to DNA-damage stress response. EMBO J 2005 , 24:3602-36I2

II. Skabkin MA, Evdokimova V, Thomas AA, Ovchinnikov LP: The major messenger ribonucleoprotein particle protein $\mathrm{p} 50$ (YB-I) promotes nucleic acid strand annealing. J Biol Chem 200I, 276:4484I-44847

12. Evdokimova VM, Wei CL, Sitikov AS, Simonenko PN, Lazarev OA Vasilenko KS, Ustinov VA, Hershey JW, Ovchinnikov LP: The major protein of messenger ribonucleoprotein particles in somatic cells is a member of the $\mathbf{Y}$-box binding transcription factor family. J Biol Chem 1995, 270:3186-3192.

13. Ise T, Nagatani G, Imamura T, Kato K, Takano H, Nomoto M, Izum $\mathrm{H}$, Ohmori H, Okamoto T, Ohga T, Uchiumi T, Kuwano M, Kohno K: Transcription factor $Y$-box binding protein I binds preferentially to cisplatin-modified DNA and interacts with proliferating cell nuclear antigen. Cancer Res 1999, 59:342-346.

14. Holm PS, Bergmann S, Jurchott K, Lage H, Brand K, Ladhoff A Mantwill K, Curiel DT, Dobbelstein M, Dietel M, Gansbacher B, Royer HD: YB-I relocates to the nucleus in adenovirusinfected cells and facilitates viral replication by inducing E2 gene expression through the E2 late promoter. J Biol Chem 2002, 277: 10427-10434

15. Kloks CP, Tessari M, Vuister GW, Hilbers CW: Cold shock domain of the human Y-box protein YB-I. Backbone dynamics and equilibrium between the native state and a partially unfolded state. Biochemistry 2004, 43:10237-10246.

16. Kloks CP, Spronk CA, Lasonder E, Hoffmann A, Vuister GW Grzesiek S, Hilbers CW: The solution structure and DNA-binding properties of the cold-shock domain of the human Y-box protein YB-I. J Mol Biol 2002, 316:3 17-326.

17. Safak M, Gallia GL, Khalili K: Reciprocal interaction between two cellular proteins, Puralpha and YB-I, modulates transcriptional activity of JCVCY in glial cells. Mol Cell Biol 1999, 19:27| 2-2723

18. Okamoto $T$, Izumi $H$, Imamura $T$, Takano $H$, Ise $T$, Uchiumi $T$, Kuwano M, Kohno K: Direct interaction of p53 with the Y-box binding protein, YB-I: a mechanism for regulation of human gene expression. Oncogene 2000, 19:6194-6202.

19. Safak M, Sadowska B, Barrucco R, Khalili K: Functional interaction between JC virus late regulatory agnoprotein and cellular $Y$. box binding transcription factor, YB-I. J Virol 2002, 76:3828-3838

20. Chansky HA, Hu M, Hickstein DD, Yang L: Oncogenic TLS/ERG and EWS/Fli-I fusion proteins inhibit RNA splicing mediated by YB-I protein. Cancer Res 200I, 6I:3586-3590.

21. Ruzanov PV, Evdokimova VM, Korneeva NL, Hershey JW, Ovchinnikov LP: Interaction of the universal mRNA-binding protein, p50, with actin: a possible link between mRNA and microfilaments. J Cell Sci 1999, I I 2(Pt 20):3487-3496.

22. Skabkin MA, Kiselyova OI, Chernov KG, Sorokin AV, Dubrovin EV Yaminsky IV, Vasiliev VD, Ovchinnikov LP: Structural organization of mRNA complexes with major core mRNP protein YB-I. Nucleic Acids Res 2004, 32:562 I-5635.

23. Vater W, Fritzsche W, Schaper A, Bohm KJ, Unger E, Jovin TM: Scanning force microscopy of microtubules and polymorphic tubulin assemblies in air and in liquid. I Cell Sci 1995, I08(Pt 3): 1063-1069.

24. Bhattacharyya B, Sackett DL, Wolff J: Tubulin, hybrid dimers, and tubulin S. Stepwise charge reduction and polymerization. Biol Chem 1985, 260:10208-10216.

25. Chernov KG, Curmi PA, Hamon L, Mechulam A, Ovchinnikov LP, Pastre $D$ : Atomic force microscopy reveals binding of mRNA to microtubules mediated by two major mRNP proteins YBI and PABP. FEBS Lett 2008, 582:2875-288

26. Feit $\mathrm{H}$, Slusarek $\mathrm{L}$, Shelanski ML: Heterogeneity of tubulin subunits. Proc Natl Acad Sci USA 197I, 68:2028-203I.

27. Mithieux G, Alquier C, Roux B, Rousset B: Interaction of tubulin with chromatin proteins. $\mathrm{HI}$ and core histones. J Biol Chem 1984, 259: |5523-|553|.

28. Job D, Valiron O, Oakley B: Microtubule nucleation. Curr Opin Cell Biol 2003, 15: III-II7.

29. Murphy DB, Borisy GG: Association of high-molecular-weight proteins with microtubules and their role in microtubule assembly in vitro. Proc Natl Acad Sci USA 1975, 72:2696-2700.
30. Palmer GR, Clark DC, Bayley PM, Sattelle DB: A quasi-elastic laser light scattering study of tubulin and microtubule protein from bovine brain. I Mol Biol 1982, 160:64|-658.

31. Spann U, Renner W, Mandelkow EM, Bordas J, Mandelkow E: Tubulin oligomers and microtubule assembly studied by timeresolved X-ray scattering: separation of prenucleation and nucleation events. Biochemistry |987, 26: | | 23- | | 32.

32. Carlier MF, Didry D, Pantaloni D: Hydrolysis of GTP associated to the formation of tubulin oligomers is involved in microtubule nucleation. Biophysical J 1997, 73:4|8-427.

33. Caudron N, Valiron O, Usson $Y$, Valiron $P$, Job D: A reassessment of the factors affecting microtubule assembly and disassembly in vitro. J Mol Biol 2000, 297:2I I-220.

34. Gard DL, Kirschner MW: Microtubule assembly in cytoplasmic extracts of Xenopus oocytes and eggs. I Cell Biol 1987, 105:2191-2201.

35. Wolff J: Promotion of microtubule assembly by oligocations: cooperativity between charged groups. Biochemistry 1998, 37:10722-10729.

36. Maccioni RB, Serrano L, Avila J, Cann JR: Characterization and structural aspects of the enhanced assembly of tubulin after removal of its carboxyl-terminal domain. Eur J Biochem 1986, I56:375-38|.

37. Jacobs M, Bennett PM, Dickens MJ: Duplex microtubule is a new form of tubulin assembly induced by polycations. Nature 1975 257:707-709.

38. Erickson HP, Voter WA: Polycation-induced assembly of purified tubulin. Proc Natl Acad Sci USA 1976, 73:28I3-28I7.

39. Melki R, Kerjan P, Waller JP, Carlier MF, Pantaloni D: Interaction of microtubule-associated proteins with microtubules: yeast lysyl- and valyl-tRNA synthetases and tau 218-235 synthetic peptide as model systems. Biochemistry I991, 30: I I536-I I545.

40. Eichenmuller B, Ahrens DP, Li Q, Suprenant KA: Saturable binding of the echinoderm microtubule-associated protein (EMAP) on microtubules, but not filamentous actin or vimentin filaments. Cell Motil Cytoskeleton 200 I, 50:161-I72.

4I. Forlani G, Baldassa S, Lavagni P, Sturani E, Zippel R: The guanine nucleotide exchange factor RasGRF I directly binds microtubules via DHPH2-mediated interaction. FEBS \& 2006 , 273:2127-2138.

42. Pedrotti B, Islam K: Purified native microtubule associated protein MAPIA: kinetics of microtubule assembly and MAPIA/ tubulin stoichiometry. Biochemistry 1994, 33: | 2463-I2470.

43. Littauer UZ, Giveon D, Thierauf M, Ginzburg I, Ponstingl H: Common and distinct tubulin binding sites for microtubule-associated proteins. Proc Natl Acad Sci USA 1986, 83:7162-7166.

44. Jansen RP: RNA-cytoskeletal associations. FASEB J 1999, 1 3:455-466.

45. Chuong SD, Good AG, Taylor GJ, Freeman MC, Moorhead GB, Muench DG: Large-scale identification of tubulin-binding proteins provides insight on subcellular trafficking, metabolic channeling, and signaling in plant cells. Mol Cell Proteomics 2004, 3:970-983.

46. Bokros CL, Hugdahl JD, Kim HH, Hanesworth VR, van Heerden A, Browning KS, Morejohn LC: Function of the p86 subunit of eukaryotic initiation factor (iso) $4 \mathrm{~F}$ as a microtubule-associated protein in plant cells. Proc Natl Acad Sci USA 1995, 92:7120-7124.

47. Evdokimova V, Ruzanov P, Anglesio MS, Sorokin AV, Ovchinnikov LP, Buckley J, Triche TJ, Sonenberg N, Sorensen PH: Akt-mediated YB-I phosphorylation activates translation of silent mRNA species. Mol Cell Biol 2006, 26:277-292.

48. Bader AG, Vogt PK: Inhibition of protein synthesis by $\mathbf{Y}$ boxbinding protein I blocks oncogenic cell transformation. Mol Cell Biol 2005, 25:2095-2106.

49. Bader AG, Felts KA, Jiang N, Chang HW, Vogt PK: Y box-binding protein I induces resistance to oncogenic transformation by the phosphatidylinositol 3-kinase pathway. Proc Natl Acad Sci USA 2003, 100:12384-12389.

50. Bader AG, Vogt PK: Phosphorylation by Akt disables the antioncogenic activity of YB-I. Oncogene 2008, 27: I I79-I I 82.

5I. Bergmann S, Royer-Pokora B, Fietze E, Jurchott K, Hildebrandt B, Trost D, Leenders F, Claude JC, Theuring F, Bargou R, Dietel M, Royer HD: YB-I provokes breast cancer through the induction of chromosomal instability that emerges from mitotic 
failure and centrosome amplification. Cancer Res 2005, 65:4078-4087.

52. Davydova EK, Evdokimova VM, Ovchinnikov LP, Hershey JW: Overexpression in COS cells of p50, the major core protein associated with mRNA, results in translation inhibition. Nucleic Acids Res 1997, 25:291।-2916.

53. Castoldi M, Popov AV: Purification of brain tubulin through two cycles of polymerization-depolymerization in a high-molarity buffer. Protein Expr Purif 2003, 32:83-88.

54. Mitchison TJ, Kirschner M: Microtubule assembly nucleated by isolated centrosomes. Nature 1984, 3 I 2:232-237.

55. Knipling L, Hwang J, Wolff J: Preparation and properties of pure tubulin S. Cell Motil Cytoskeleton 1999, 43:63-7I.

56. Miwa A, Higuchi T, Kobayashi S: Expression and polysome association of $\mathrm{YB}-\mathrm{I}$ in various tissues at different stages in the lifespan of mice. Biochim Biophys Acta 2006, 1760:1675-I68I.

57. Curmi PA, Andersen SSL, Lachkar S, Gavet O, Karsenti E, Knossow $M$, Sobel A: The stathmin/tubulin interaction in vitro. J Biol Chem 1997, 272:25029-25036.

58. Pastre D, Pietrement O, Fusil S, Landousy F, Jeusset J, David MO, Hamon L, Le Cam E, Zozime A: Adsorption of DNA to mica mediated by divalent counterions: a theoretical and experimental study. Biophys / 2003, 85:2507-25 I8.

59. Svetlov MS, Kommer A, Kolb VA, Spirin AS: Effective cotranslational folding of firefly luciferase without chaperones of the Hsp70 family. Protein Sci 2006, I5:242-247.

Publish with Bio Med Central and every scientist can read your work free of charge

"BioMed Central will be the most significant development for disseminating the results of biomedical research in our lifetime. "

Sir Paul Nurse, Cancer Research UK

Your research papers will be:

- available free of charge to the entire biomedical community

- peer reviewed and published immediately upon acceptance

- cited in PubMed and archived on PubMed Central

- yours - you keep the copyright

Submit your manuscript here:

http://www.biomedcentral.com/info/publishing_adv.asp
BioMedcentral 